\title{
Amelioration of Delayed Neuronal Death in the Hippocampus by Nerve Growth Factor
}

\author{
Taku Shigeno, ${ }^{1}$ Tatsuo Mima, ${ }^{2}$ Kintomo Takakura, ${ }^{2}$ David I. Graham, ${ }^{3}$ Gunshiro Kato, ${ }^{4}$ Yoshihide Hashimoto, ${ }^{5}$ \\ and Shoei Furukawa ${ }^{5}$ \\ 'Department of Neurosurgery, Saitama Medical Center, Saitama Medical School, Kawagoe, Saitama 350, Japan, \\ 2Department of Neurosurgery, University of Tokyo, Bunkyo, Tokyo 113, Japan, ${ }^{3}$ Department of Neuropathology, University \\ of Glasgow, Glasgow G51 4TF, United Kingdom, ${ }^{4}$ Department of Neuroanatomy, Chiba College of Health Science, Chiba \\ 260, Japan, and ${ }^{5}$ Department of Molecular Biology, Gifu Pharmacological University, Gifu 502, Japan
}

\begin{abstract}
Selective neuronal death in the CA1 sector of the hippocampus [delayed neuronal death (DND)] develops several days after transient global cerebral ischemia in rodents. Because NGF plays a potential role in neuronal survival, it was decided to study its effect in DND. We report here that intraventricular injection of NGF either before or after 5 min forebrain ischemia in the Mongolian gerbil significantly reduced the occurrence of DND. The tissue content of NGF in the hippocampus was decreased $2 \mathrm{~d}$ after ischemia and recovered to the preischemic level by 1 week. By the Golgi staining technique, changes first began in the dendrites of affected neurons as early as $3 \mathrm{hr}$. Such changes could be ameliorated by NGF treatment. Although previous knowledge of NGF is limited to the survival of cholinergic neurons in the CNS, it is assumed that other mechanisms must be operating in the hippocampus, for example, postsynaptic modification at dendrites or aberrant expression of NGF receptors possibly at the initial excitation period by glutamate. Furthermore, because previous work has shown that inhibition of protein synthesis reduces the occurrence of DND, a program leading to cell death might also be operating via de novo synthesis of certain protein(s), collectively termed "killer protein," because of a lack of NGF.
\end{abstract}

The hippocampus is unique in the CNS because of its relative simplicity of excitatory neuronal circuitry and its role in mnemonic function (Brown et al., 1988; Press et al., 1989; Brown and Zador, 1990). After temporal cessation of cerebral circulation, patients develop memory disturbance with hippocampal neuronal death (Brierley and Graham, 1984). In rodents, delayed neuronal death (DND) of the CAl sector of the hippocampus develops more than $2 \mathrm{~d}$ after transient global cerebral ischemia (Ito et al., 1975; Kirino, 1982). This phenomenon has been thought to underlie the pathophysiology of cerebrovascular dementia.

Received Oct. 26, 1990; revised Apr. 11, 1991; accepted Apr. 16, 1991.

We thank Mrs. Reiko Matsu-ura and Miss Chicko Mizunuma (University of Tokyo), Mr. Len Miller (University of Glasgow), Mrs. Kazuyo Kusaka (Chiba College of Health Science), Dr. Noriaki Ikeda (Mitsui Pharmaceuticals), and Dr. Tsutomu Imura and Dr. Kei Nakajima (Yoshitomi Pharmaceuticals) for their continuous help. We are particularly grateful to Miss Yoko Muto, Mrs. Yuriko Seino, and Mr. Noboru Sunaga (University of Tokyo) for animal care.

Correspondence should be addressed to Taku Shigeno, M.D., at the above address.

Copyright (C) 1991 Society for Neuroscience $0270-6474 / 91 / 112914-06 \$ 03.00 / 0$
The initiating event that leads to DND of the hippocampus is possibly neural excitation caused by glutamate and subsequent calcium influx into the cell (Nadler et al., 1978; Gill et al., 1987; Barnes, 1988a; Choi and Rothman, 1990). However, this mechanism cannot fully explain why the development of DND is delayed and why the occurrence is mainly limited to the CA1 sector. We assume it is due to a failure of recovery processes following excitatory damage to this particular neural circuitry. As one of the possible factors for neuronal survival and repair known to date, we have focused on NGF (Marx, 1986; LeviMontalcini, 1987). Neuronal cell loss could be caused by a lack of such neurotrophic factors (Hefti et al., 1984; Hefti and Weiner, 1986; Fisher et al., 1987; Kromer, 1987; Rosenberg et al., 1988; Montero and Hefti, 1989). Although until quite recently there has been no thorough explanation of why NGF acts in the hippocampus, evidence is now accumulating that NGF receptors are also present in the hippocampus during development (Buck et al., 1988; Lu et al., 1989), and also in the mature brain (Kerwin et al., 1991). The principal aim of this study was to investigate whether NGF affects the occurrence of DND by injecting NGF into the cerebral ventricle either before or after transient forebrain ischemia in the Mongolian gerbil. It was found that intraventricular NGF ameliorated the development of DND.

\section{Materials and Methods}

We utilized the standard experimental protocol to produce DND in terms of animal species, duration of ischemia, and anesthesia. Adult male Mongolian gerbils weighing about $70 \mathrm{gm}$ (9-12 birth weeks) were anesthetized with $2-3 \%$ halothane/ $\mathrm{O}_{2}$. Transient forebrain global ischemia was produced by occluding bilateral carotid arteries for $5 \mathrm{~min}$ using aneurysm clips. Rectal temperature was kept as close as possible to $38^{\circ} \mathrm{C}$ during and up to $1 \mathrm{hr}$ after ischemia with the aid of a heating blanket and overhead lamp. The animals were then allowed to survive for 1 week before transcardiac perfusion fixation with $40 \%$ formaldehyde, glacial acctic acid, and methanol in a volume ratio of 1:8:8. Neuropathological studies were undertaken in four groups of animals: (1) occlusion alone $(n=12)$, (2) intraventricular injection of $10 \mu \mathrm{l}$ of artificial cerebrospinal fluid (CSF) warmed to $37^{\circ} \mathrm{C}$ (in $\mathrm{mM} ; \mathrm{Na}^{+}, 145$; $\mathrm{K}^{+}, 3.0 ; \mathrm{Cl}^{-}, 132 ; \mathrm{Ca}^{2+}, 2.4 ; \mathrm{Mg}^{2+}, 1.2 ; \mathrm{HCO}_{3}{ }^{-}, 26 ; \mathrm{H}_{2} \mathrm{PO}_{4}^{-}, 1.2 ; \mathrm{SO}_{4}{ }^{2-}$ 1.2; glucose, $10 ; \mathrm{pH} 7.3 ; n=12$ ), (3) intraventricular injection of NGF (Sigma 7S type; $10 \mu \mathrm{g}$ in $10 \mu \mathrm{l}$ of artificial CSF) just before ischemia ( $n$ $=12$ ), and (4) same as treatment 3 but $15 \mathrm{~min}$ after ischemia $(n=12)$. Treatment of NGF was given via a needle inserted into the right lateral ventricle. The target point was $1 \mathrm{~mm}$ anterior to the bregma, $1.25 \mathrm{~mm}$ lateral to the midline, and $2.25 \mathrm{~mm}$ deep from the cortical surface. Ten micron-thick sections at the dorsal hippocampus were stained with hematoxylin-eosin and cresyl violet. The number of neurons in the bilateral CAl subfield was counted on one histological section from 
each animal and expressed as neuronal cell density per millimeter linear length. Sections obtained from normal control animals $(n=7)$ were also examined. For statistical purposes, we utilized both the analysis of variance (ANOVA) and the nonparametric Kruskal-Wallis test for comparison of multiple independent groups.

The Golgi staining technique was used in a separate series of three animals each to see morphological changes in dendrites and synapses $3 \mathrm{hr}, 1 \mathrm{~d}, 2 \mathrm{~d}$, and 1 week postischemia in gerbils both nontreated and pretreated with NGF. The brain was removed and quickly immersed in a mixture of solutions $A$ and $B$ : solution $A$ contained potassium dichromate and mercury chloride; solution B contained potassium chromate and sodium tangstenate. Following immersion for 1 month, the brains were processed for microscopic examination.

We investigated sequential changes in the hippocampal NGF content before and $3 \mathrm{hr}, 1 \mathrm{~d}, 2 \mathrm{~d}$, and 1 week after ischemia in a total of 31 gerbils. We utilized the two-site enzyme immunoassay (EIA) system developed by Furukawa et al. (1983) with a slight modification (Matsui et al., 1990).

\section{Results}

The gerbils survived well, and no seizures were observed either in the acute stage of ischemia or up to 1 week later. Although there was a mortality of less than $10 \%$ up to 1 week, there was no difference between the five groups of treatment.. Neuropathological studies were not undertaken on the gerbils that died. Neuropathological studies showed that NGF significantly ameliorated the development of DND (Fig. 1). There was a statistically significant difference of $p<0.001$ among the five groups by ANOVA. However, the distribution was not even, so the nonparametric analysis of Kruskal-Wallis was also used. It, too, showed a significant difference of $p<0.001$ among all the groups. For comparison of two groups, the nonparametric Wilcoxon test as shown in Figure 1 was used. In all the gerbils with occlusion alone, there was almost complete loss of CAl pyramidal neurons. However, injection of artificial CSF before ischemia showed a slight but significant effect in reducing DND as compared to the nontreated gerbils $(p<0.05)$. Using NGF treatment either before or after ischemia, the cell density remained almost normal. When compared to the controls sham treated with artificial CSF injection, there was a significant difference for both pretreatment $(p<0.01)$ and posttreatment $(p<0.05)$ groups. The cell density of the pretreatment group did not differ from that of the posttreatment group.

In the Golgi study, morphological changes appeared in dendrites and synaptic spines as early as $3 \mathrm{hr}$, even though the cell soma looked entirely normal (Figs. 2, 3). After $1 \mathrm{~d}$, there was progressive disappearance of both basal and apical dendrites. By 1 week, the CAl sector had been replaced by reactive astroglia in the nontreated gerbils. Following NGF treatment, these dendritic changes were minimal, with only a slight astroglial reaction.

There was a significant reduction in NGF content of the hippocampus $2 \mathrm{~d}$ after ischemia, with subsequent recovery to the control level after 1 week (Fig. 4). In the other areas of the brain, no significant changes were found (data not shown).

\section{Discussion}

The development of DND is a complex process that involves initiation and subsequent so-called maturation (Ito et al., 1975), probably similar to long-term potentiation (Brown et al., 1988). In the past, the initiating neuroexcitatory mechanisms have received much interest. Glutamate is one compound that acts at the postsynaptic level via NMDA receptor (Nadler et al., 1978; Gill et al., 1987; Barnes, 1988a; Choi and Rothman, 1990) or

\section{Neuronal Cell Density per $1 \mathrm{~mm}$ in the CAl Subfield of Hippocampus}

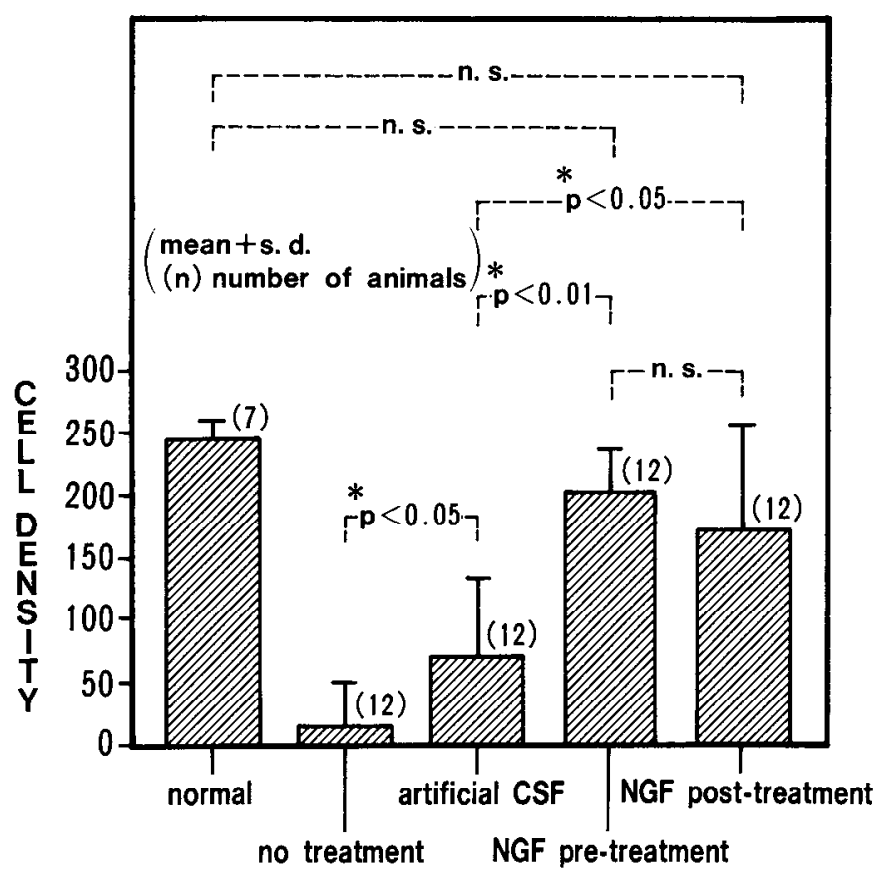

Figure 1. Results of neuropathological study. Values are mean \pm SD of cell number per millimeter in the CAl sector of the hippocampus. $\mathrm{NGF}$ treatment either before or after ischemia significantly ameliorated the development of neuronal death as compared to control with artificial CSF injection (Wilcoxon's nonparametric analysis). Artificial CSF injection alone slightly but significantly reduced the extent of neuronal death as compared to animals without treatment. The cell density of both pre- and posttreatment groups did not differ from normal cell density.

other receptors such as quisqualate and kainate (Sheardown et al., 1990). Indeed, antagonists against NMDA, quisqualate, and kainate receptors have been reported to reduce DND if given before ischemia (Gill et al., 1987; Sheardown et al., 1990), although uncertainty remains. After such events, manipulations that decrease cellular metabolism immediately after ischemia by barbiturate (Kirino et al., 1985) or by lowering brain temperature (Busto et al., 1987) can reduce the amount of DND. Little is known regarding the subsequent maturation stage, but some information about postischemic protein synthesis is now accumulating (Thilman et al., 1986; Xie et al., 1989). For example, it has been shown that amino acid incorporation is inhibited transiently but recovers in the hippocampus after ischemia except in the vulnerable CA1 neurons. Some translation products related to stress such as heat-shock proteins and ubiquitin are known to increase (Nowak, 1985; Vass et al., 1988; Magnusson and Wieloch, 1989; Nowak et al., 1990). The expression of mRNAs for these proteins is pronounced in the dentate granule cells and $\mathrm{CA} 3$ neurons. These areas are intrinsic afferents to $\mathrm{CA} 1$ neurons, so there may be some modification of synaptic responses by such translation products in the CA1 sector.

The present study indicates a new finding that NGF is required for the survival of hippocampal neurons in response to ischemia. Yoshimine et al. (1991) have independently repeated a similar experiment and obtained the same results. In support 


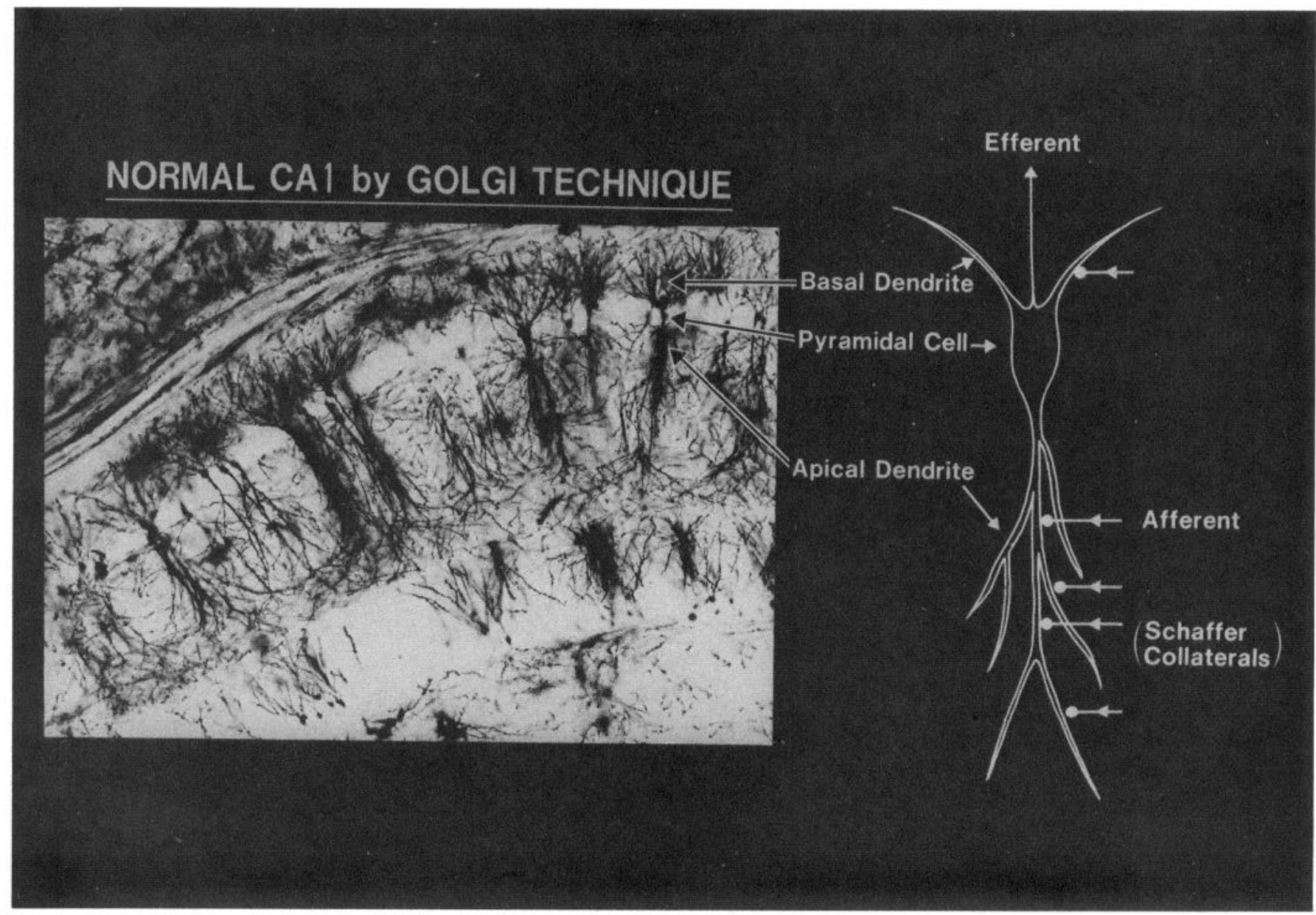

Figure 2. Appearance of the normal CA1 sector of the hippocampus stained by the Golgi technique. The drawing to the right shows dendritic structures of single pyramidal neuron in relation to its afferent synaptic connections.

of this finding, it has been reported that damage to the striatum and hippocampus caused by glutamate agonists can be prevented by intracerebral injection of NGF (Aloe, 1987).

However, caution must be taken to avoid the possibility of artifact. First, the NGF used in this study was the 7S type, which contains some protease activity. Most previous investigators have also used this type of NGF in a wide range of investigations. In particular, Fisher et al. (1987) treated aged rats with 7S-type NGF and found amelioration of behavior and neuropathology. We are currently repeating the experiment by using $\beta$-NGF. Our preliminary result is in agreement with the present study ( $\mathrm{T}$. Shigeno, T. Mima, K. Takakura, D. I. Graham, G. Kato, Y. Hashimoto, and S. Fukurawa, unpublished observations).

Second, the use of anesthesia during ischemia might have interfered with the results. Barbiturates certainly ameliorate the phenomenon of DND (Kirino et al., 1985). Halothane has been widely used in the gerbil ischemia model but has not been reported to show such action as long as body temperature is maintained above $37^{\circ} \mathrm{C}$ during and shortly after ischemia (Kuroiwa et al., 1990). Furthermore, although a wide range of anesthetics have been used in the study of fimbria-fornix section and to examine the effects of NGF, none have been reported to influence the results. Therefore, we think that the issue of anesthesia is not a significant factor in the present experiment.

Third, it should be noted that gerbils are seizure prone. After unilateral occlusion of the carotid artery, seizures occur occasionally. However, when the occlusion is bilateral and the duration of ischemia is limited to $5 \mathrm{~min}$ under halothane anesthesia, seizures have not been observed, and the mortality ratio is negligible (Tomida et al., 1987). Therefore, the experimental model and method we used is now a standard accepted worldwide. Even so, there may be a possibility of subclinical seizure that compromises NGF action, because Gall and Isackson (1989) reported increased NGF mRNA in the hippocampus by limbic seizure or by kainate-induced seizures (Gall et al., 1991), with a possible link to c-fos expression (Morgan et al., 1987). It is also of interest to note that intraventricular injection of NGF antiserum inhibits amygdaloid kindling (Funabashi et al., 1988). Thus, the effect of the exogenously administered NGF in our study might have been derived from such seizure-related events. Indeed, this mechanism could underlie the pathogenesis of DND.

Conventional wisdom indicates that NGF is synthesized in the hippocampus and is transported retrogradely to the basal forebrain neurons (Korshing et al., 1985; Large et al., 1986). It has been established that NGF is essential for the survival of cholinergic neurons in the basal forebrain (Hefti et al., 1984; Hefti and Weiner, 1986; Marx, 1986; Fisher et al., 1987; Kromer, 1987; Levi-Montalcini, 1987; Rosenberg et al., 1988; Montero and Hefti, 1989). On the contrary, there is no concrete evidence that hippocampal neurons require NGF for their sur- 


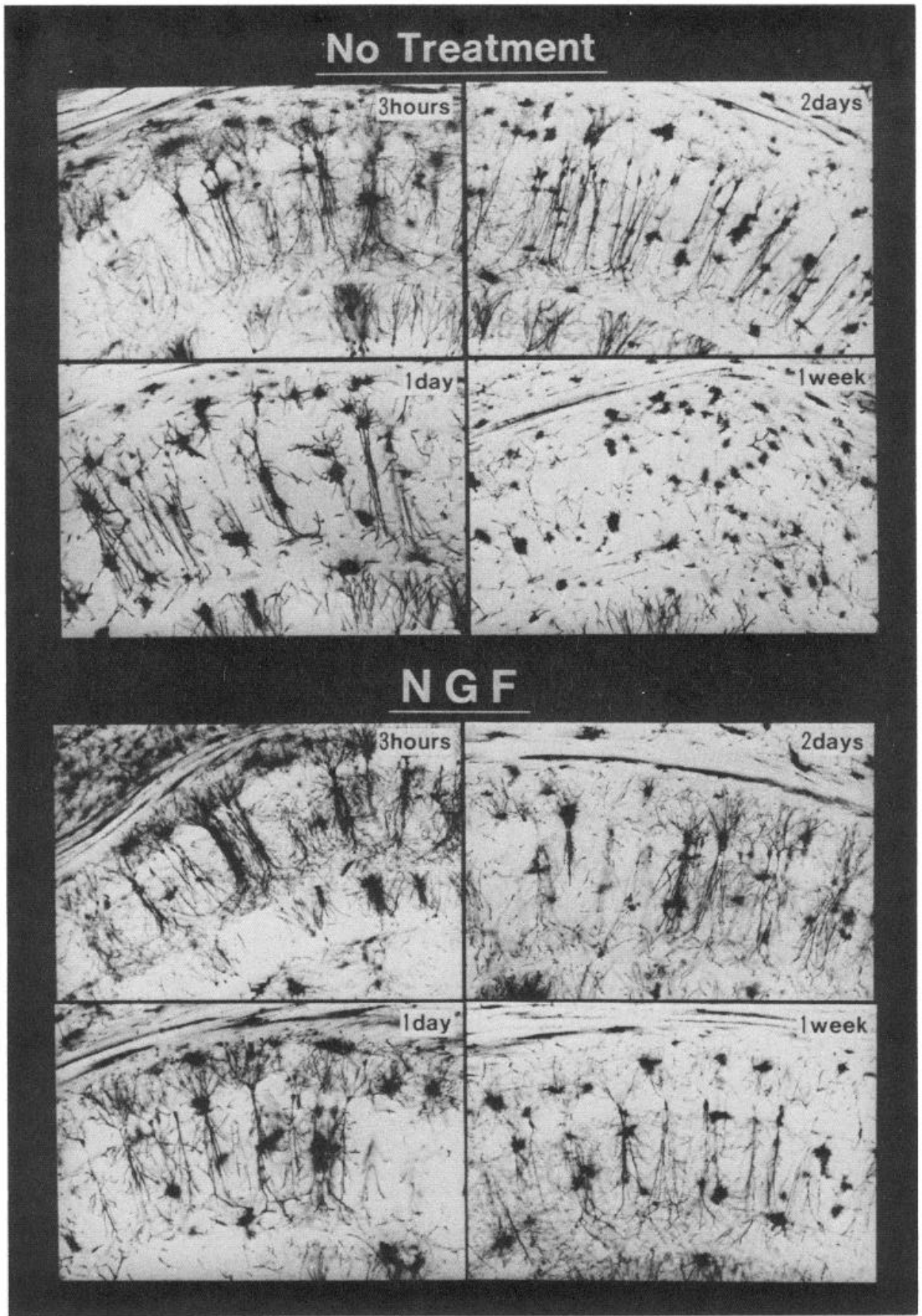

Figure 3. Chronological changes of dendritic structures after ischemia. Top, no treatment; bottom, treatment with NGF before ischemia. Three hours after ischemia in the nontreated gerbils, there was slight deformation of both basal and apical dendrites. These changes progressed with disappearance of these dendritic structures on days 1 and 2, even though the cell soma was still present. After 1 week, all the pyramidal cells together with dendrites disappeared without NGF treatment. Treatment with NGF prevented the early destruction of dendritic structures.

vival. In the past, NGF receptors were reported to be absent or very scanty in the hippocampus (Richardson et al., 1986; Raivich and Kreutzberg, 1987). However, Buck et al. (1988) have recently identified temporary expression of NGF receptor mRNA in the hippocampus during development. The fact that NGF and its receptor mRNAs were coexpressed and correlated developmentally in the hippocampus indicates that NGF may serve not only as a target-derived factor acting on long-projecting neurons, but also as a locally derived factor acting on intrinsic neurons in a paracrine or autocrine fashion ( $\mathrm{Lu}$ et al., 1989). Indeed, very recently, Kerwin et al. (1991) were the first to demonstrate NGF receptors in the human adult hippocampus. They found that the preterminal NGF receptor network was dense in CA2-CA3 and diminished in intensity through $\mathrm{CA} 1$ and toward the subiculum. Because evidence of the presence of NGF receptor in the hippocampus is increasing, there is good reason to believe that the exogenously administered NGF acts via expression of NGF receptor of CA1 pyramidal neurons shortly after cerebral ischemia.

The slight but statistically significant effect in reducing DND by injection of artificial CSF as a vehicle is worthy of discussion. It is known that several types of brain tissue trauma or hypoxia induce trophic factors such as NGF and fibroblast growth factor (FGF; Nieto-Sampedro et al., 1982, 1988; Lorez et al., 1989; Ishikawa et al., 1991). In the present study, we observed a transient decrease in hippocampal tissue NGF content on day 2 and 


\section{Hippocampal NGF Content after $5 \mathrm{~min}$ Ischemia}

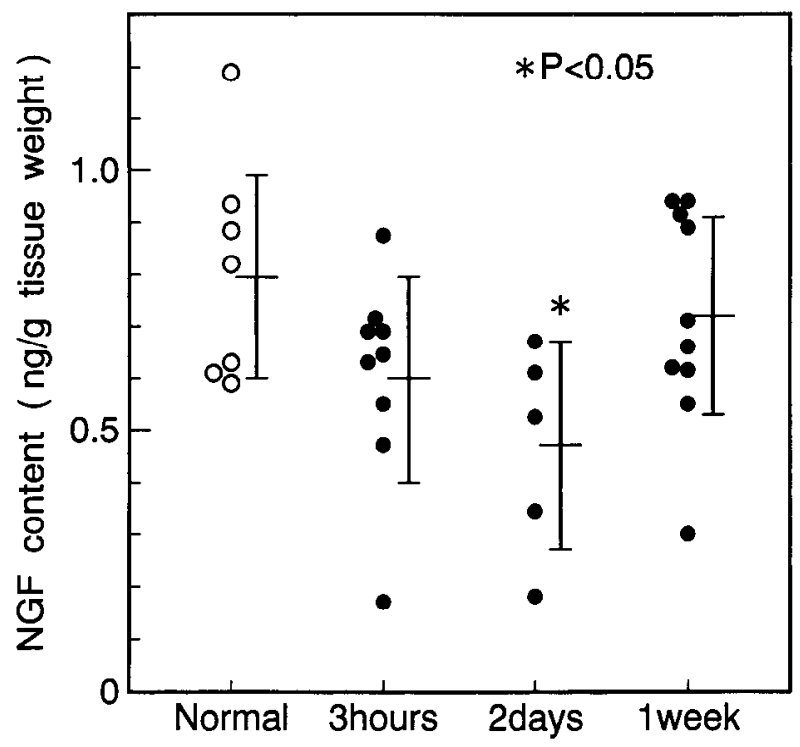

Figure 4. Changes in NGF content in the hippocampus after ischemia. Values are mean $\pm \mathrm{SD}$. There was a significant reduction in NGF content $2 \mathrm{~d}$ after ischemia. After 1 week, however, the NGF content recovered to the control level.

recovery by 1 week after ischemia. At this stage, there was a marked appearance of reactive astrogitia in the Golgi study. The recovery in NGF content might suggest a role of astrocytes in tissue repair, because glial cells could secrete NGF in culture (Furukawa et al., 1986). Although we did not measure NGF content in the much earlier period, such tissue trauma with brain tissue puncture might have elevated local tissue NGF content and thus ameliorated DND partially by the following reasons. First, Ishikawa et al. (1991) found a steep increase in cortical NGF content following a cavity lesioning as early as $16 \mathrm{hr}$, in contrast to FGF, which became elevated more than $10 \mathrm{~d}$ later. A glial and/or neuronal origin of the NGF was thought to be most likely. Second, Yoshimine et al. (1990) found a slight but significant reduction of DND even after only a needle puncture into the hippocampus. In our study, we administered NGF just before or after ischemia. Yoshimine et al. (1990) further examined the optimal time of treatment and found that NGF acted only in the earlier period, within $1 \mathrm{~d}$ after ischemia. Therefore, the possible increase of such neurotrophic activity in the earlier period may be one of the reasons for the results found after artificial CSF injection.

There is a suggestion that neuronal death caused by a lack of NGF results from the operation of a suicidal program via de novo synthesis of protein(s), collectively termed "killer protein" (Barnes, 1988b; Martin et al., 1988; Oppenheim et al., 1988). Even the neuronal death of the CA1 sector might be a CNS response to reduce harmful neuroexcitation in and around the hippocampus. In this regard, it is of interest to note that transection of afferents in the perforant path prevents DND (Wieloch et al., 1985). We have recently reported that inhibition of protein synthesis before ischemia also reduces the occurrence of DND (Shigeno et al., 1990). As was discussed above, several species of proteins and protooncogenes such as c-fos (Jorgensen et al., 1989) are expressed before maturation of cell death. There is a chain of events that starts with glutamate neuroexcitation and is followed by signal protooncogene expression and protein synthesis that leads to DND. It would seem that NGF is involved in this process.

\section{References}

Aloe L (1988) Intracerebral pretreatment with nerve growth factor prevents irreversible brain lesions in neonatal rats injected with ibotenic acid. Biotechnology 5:1085-1086.

Barnes DM (1988a) NMDA receptors trigger excitement. Science 239: 254-256.

Barnes DM (1988b) Cells without growth factors commit suicide. Science 242:1510-1511.

Brierley JB, Graham DI (1984) Hypoxia and vascular disorders of the central nervous system. In: Greenfield's neuropathology (Adams JH, Corsellis JAN, Duchen LW, eds), pp 125-207. New York: Wiley.

Brown TH, Zador AM (1990) Hippocampus. In: The synaptic organization of the brain (Shepherd GM, ed), pp 346-388. New York: Oxford UP.

Brown TH, Chapman PF, Kairiss EW, Keenan CL (1988) Long-term synaptic potentiation. Science 242:724-728.

Buck CR, Martinez HJ, Chao MD, Black IB (1988) Differential expression of the nerve growth factor receptor in multiple brain areas. Dev Brain Res 44:259-268.

Busto R, Dietrich WD, Globus MYT, Valdes I, Scheinberg P, Ginsberg MD (1987) Small differences in intraischemic brain temperature critically determine the extent of ischemic neuronal injury. J Cereb Blood Flow Metab 7:729-738.

Choi DW, Rothman SM (1990) The role of glutamate neurotoxicity in hypoxic-ischemic neuronal death. Annu Rev Neurosci 13:171182.

Fisher W, Wictorin K, Björklund A, Williams LR, Varon S, Gage FH (1987) Amelioration of cholinergic neuron atrophy and spatial memory impairment in aged rats by nerve growth factor. Nature 329:6568.

Funabashi T, Sasaki H, Kimura F (1988) Intraventricular injection of antiserum to nerve growth factor delays the development of amygdaloid kindling. Brain Res 458:132-136.

Furukawa S, Kamo I, Furukawa Y, Akazawa S, Satoyoshi E, Itoh K, Hayashi K (1983) A highly sensitive enzyme immunoassay for mouse $\beta$ nerve growth factor. J Neurochem 40:734-744.

Furukawa S, Furukawa Y, Satoyoshi E, Hayashi K (1986) Synthesis and secretion of nerve growth factor by mouse astroglial cells in culture. Biochem Biophys Res Commun 136:57-63.

Gall C, Murray K, Isackson PJ (1991) Kainic acid-induced seizures stimulate increased expression of nerve growth factor mRNA in rat hippocampus. Mol Brain Res 9:113-123.

Gall CM, Isackson PJ (1989) Limbic seizures increases neuronal production of messenger RNA for nerve growth factor. Science 245:758761 .

Gill R, Foster AC, Woodruff GN (1987) Systemic administration of MK-801 protects against ischemia-induced hippocampal neurodegeneration in the gerbil. J Neurosci 7:3343-3349.

Hefti F, Weiner WJ (1986) Nerve growth factor and Alzheimer's disease. Ann Neurol 20:275-281.

Hefti F, Dravid A, Hartikka J (1984) Chronic intraventricular injections of nerve growth factor elevate hippocampal acetylcholine transferase activity in adult rats with partial septohippocampal lesions. Brain Res 293:305-311.

Ishikawa R, Nishikiori K, Furukawa S (1991) Appearance of ncrve growth factor and acidic fibroblast growth factor with different time courses in the cavity-lesioned cortex of the brain. Neurosci Lett, in press.

Ito U, Spatz M, Walker JT Jr, Klatzo I (1975) Experimental cerebral ischemia in Mongolian gerbils. I. Light microscopic observations. Acta Neuropathol (Berl) 32:209-223.

Jorgensen MB, Deckert J, Wright DC, Gehlert DR (1989) Delayed c-fos proto-oncogene expression in the rat hippocampus induced by transient global cerebral ischemia: an in situ hybridization study. Brain Res 484:393-398.

Kerwin J, Morris C, Oakley A, Perry R, Perry E (1991) Distribution of nerve growth factor receptor immunoreactivity in the human hippocampus. Neurosci Lett 121:178-182. 
Kirino $T$ (1982) Delayed neuronal death in the gerbil hippocampus following ischemia. Brain Res 239:57-69.

Kirino T, Tamura A, Sano K (1985) A reversible type of neuronal injury following ischemia in the gerbil hippocampus. Stroke 17:455459.

Korshing S, Auburger G, Heuman R, Scott J, Thoenen H (1985) Levels of nerve growth factor and its mRNA in the central nervous system of the rat correlate with cholinergic innervation. EMBO J 4:13891393.

Kromer LF (1987) Nerve growth factor treatment after brain injury prevents neuronal death. Science 235:214-216.

Kuroiwa T, Bonnekoh P, Hossmann KA (1990) Prevention of postischemic hyperthermia prevents ischemic injury of CA1 neurons in gerbils. J Cereb Blood Flow Metab 10:550-556.

Large TH, Bodary SC, Clegg DO, Weskamp G, Otten U, Reichardt LF (1986) Nerve growth factor gene expression in the developing rat brain. Science 234:352-355.

Levi-Montalcini R (1987) The nerve growth factor 35 years later. Science 237:1154-1162.

Lorez H, Keller F, Ruess G, Otten U (1989) Nerve growth factor increases in adult rat brain after hypoxic injury. Neurosci Lett 98: 339-344.

Lu B, Buck CR, Dreyfus CF, Black IB (1989) Expression of NGF and NGF receptor $m R N A s$ in the developing brain: evidence for local delivery and action of NGF. Exp Neurol 104:191-199.

Magnusson K, Wieloch T (1989) Impairment or protein ubiquitization may cause delayed neuronal death. Neurosci Lett 96:264-270.

Martin DP, Schmidt RE, DiStefano PS, Lowry OH, Carter JG, Johnson EM Jr (1988) Inhibitors of protein synthesis and RNA synthesis prevent neuronal death caused by nerve growth factor deprivation. $J$ Cell Biol 106:829-844.

Marx JL (1986) Nerve growth factor acts in brain. Science 232:13411342.

Matsui K, Furukawa S, Shibasaki H, Kikuchi T (1990) Reduction of nerve growth factor level in the brain of genetically ataxic mice (weaver, reeler). FEBS Lett 276:78-80.

Montero CN, Hefti F (1989) Intraventricular nerve growth factor administration prevents lesion-induced loss of septal cholinergic neurons in aging rats. Neurobiol Aging 10:739-743.

Morgan JI, Cohen DR, Hempstead JL, Curran T (1987) Mapping patterns of c-fos expression in the central nervous system after seizure. Science 237:192-197.

Nadler JV, Perry BW, Cotman CW (1978) Intraventricular kainic acid preferentially destroys hippocampal pyramidal cells. Nature 271:676677.

Nieto-Sampedro M, Lewis ER, Cotman CW, Manthorpe M, Skaper SD, Barbin G, Longo FM, Varon S (1982) Brain injury causes a timedependent increase in neurotrophic activity at the lesion site. Science 217:860-861.

Nieto-Sampedro M, Lim R, Hicklin DJ, Cotman CW (1988) Early release of glia maturation factor and acidic fibroblast growth factor after rat brain injury. Neurosci Lett 86:361-365.

Nowak TS Jr (1985) Synthesis of a stress protein following transient ischemia in the gerbil. J Neurochem 45:1635-1641.

Nowak TS Jr, Bond U, Schlesinger MJ (1990) Heat shock RNA levels in brain and other tissues after hyperthermia and transient ischemia. J Neurochem 54:451-458.

Oppenheim RW, Haverkamp LJ, Prevette D, McManaman JL, Appel SH (1988) Reduction of naturally occurring motoneuron death in vivo by a target-derived neurotrophic factor. Science 240:919-922.

Press GA, Amarai DG, Squire LR (1989) Hippocampal abnormalities in amnesic patients revealed by high-resolution magnetic resonance imaging. Nature 341:54-57.

Raivich G, Kreutzberg GW (1987) The localization and distribution of high affinity $\beta$-nerve growth factor binding sites in the central nervous system of the adult rat. A light microscopic autoradiographic study using [ $\left.{ }^{125} \mathrm{I}\right] \beta$-nerve growth factor. Neuroscience 20:23-36.

Richardson PM, Verge Issa VMK, Riopelle RJ (1986) Distribution of neuronal receptors for nerve growth factor in the rat. J Neurosci 6:2312-2321.

Rosenberg MB, Friedmann T, Robertson RC, Tuszynski M, Wolff JA Breakefield XO, Gage FH (1988) Grafting genetically modified cells to the damaged brain: restorative effects of NGF expression. Science 242:1575-1578.

Sheardown MJ, Nielsen EØ, Hansen AJ, Jacobson P, Honoré T (1990) 2,3-Dihydroxy-6-nitro-7-benzo(F)quinoxaline: a neuroprotectant for cerebral ischemia. Science 247:571-574.

Shigeno T, Yamasaki Y, Kato G, Kusaka K, Mima T, Takakura K, Graham DI, Furukawa S (1990) Reduction of delayed neuronal death by inhibition of protein synthesis. Neurosci Lett 120:117-119.

Thilman R, Xie Y, Kleinhaus P, Kiessling M (1986) Persistent inhibition of protein synthesis precedes delayed neuronal death in postischemic gerbil hippocampus. Acta Neuropathol (Berl) 71:88-93.

Tomida S, Nowak TS Jr, Vass K, Lohr JM, Klatzo I (1987) Experimental model for repetitive ischemic attacks in the gerbil: the cumulative effect of repeated ischemic attacks. J Cereb Blood Flow Metab 7:773-782.

Vass K, Welch WJ, Nowak TS Jr (1988) Localization of 70-kDa stress protein induction in gerbil brain after ischemia. Acta Neuropathol (Berl) 77:128-135.

Wieloch T, Lindvall O, Blomqvist P, Gage F (1985) Evidence for amelioration of ischemic neuronal damage in the hippocampal formation by lesions of the perforant path. Neurol Res 7:24-26.

Xie Y, Seo K, Hossmann KA (1989) Effect of barbiturate treatment on post-ischemic protein biosynthesis in gerbil brain. J Neurol Sci 92:317-328.

Yoshimine T, Hayakawa T, Yamamoto S, Kimura E, Iris T, Fujioka K (1990) Effect of nerve growth factor on the development of postischemic neuronal death. Paper presented at the Ninth International Congress of Neuropathology, Kyoto, Japan. 